\title{
CONCENTRATION, FOREIGN PARTICIPATION AND BANK PERFORMANCE: AN EMPIRICAL STUDY OF ASIAN EMERGING MARKETS
}

\section{Ting-Kun Liu}

\author{
Department of Finance, Chaoyang University of Technology, Taiwan. \\ Email:tkliu@cyut.edu.tw Tel:886-4-23323000ext.4881
}

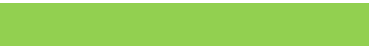

Article History

Received: 10 November 2021 Revised: 13 December 2021 Accepted: 28 December 2021 Published: 17 January 2022

\section{Keywords \\ Bank spreads \\ Foreign bank participation Market concentration The degree of competition Asian emerging market P-R model.}

\section{JEL Classification:} Foo; G21.

\section{ABSTRACT}

There is an abundance of literature on the relationship between market structure and profitability. Market share and concentration are usually analytical tools serving as indicators of market structure. There have been many empirical studies based on the structure-conduct-performance (SCP) theory. However, the correlation between market structure and bank interest spread has rarely been discussed in depth. Therefore, this paper constructs financial industry firm-level panel data of Asian emerging market countries from 2001 to 2015 to further explore the impacts of foreign bank participation, financial market concentration and the level of competition on bank spreads. Apart from the differences in samples, the most significant difference from the previous literature is that this paper considers the best indicators of competitiveness, namely the $\mathrm{H}$ value of the Panzar-Rosse (P-R) model to measure the banking market and competitive conditions. This study provides a more complete and detailed analysis by adopting the system GMM approach to perform the estimation and avoid the problem of endogeneity. Regarding the overall sample, the participation of foreign banks has had a positive and significant impact on bank interest spread, suggesting that the participation of foreign banks is a major factor influencing bank interest spread in the general financial markets in Asian emerging market countries, and that more foreign banks in local financial markets can help improve bank performance.

Contribution/Originality: This study is one of very few which have investigated this issue in newly industrialized economies (NIEs). The results based on Taiwan's experience could serve as a valuable reference for other developing countries.

\section{INTRODUCTION}

With the liberalization and globalization of financial markets, inter-bank competition in traditional business is becoming increasingly fierce. Levine \& Zervos (1996) argue that financial deepening is a fundamental and necessary factor in the process of economic growth, and inappropriate financial repression will hurt economic growth. Peria \& Mody (2004) point out that the market structure of the banking industry in developing countries has changed significantly, especially with the expansion of foreign banks in domestic financial markets.

In the last two decades, foreign banks, such as Standard Chartered Bank, ABN AMRO, Citibank and HSBC, have been rushing to establish themselves in Taiwan's domestic financial markets. In addition, in Eastern Europe during the period from 1994-1998, the ratio of domestic bank assets held by foreign banks rose from $7.8 \%$ to $52.3 \%$ compared to the increase in Latin America from 13.1\% to 44.8\%. In Mexico, foreign bank participation rose from $2 \%$ to $83 \%$ in terms of assets held between 1997 and 2005 (Beck \& Peria, 2010). According to Degirmen (2011), the 
foreign bank participation rate is currently $82 \%$ in Mexico, $48 \%$ in Argentina, $42 \%$ in Chile, $47 \%$ in Peru, $65 \%$ in both Poland and Hungary, 95\% in the Czech Republic, 93\% in Slovakia, and was already 100\% in Estonia in 2006. Foreign bank presence had increased from 30\% in 2000 to $43 \%$ in 2012 (Ghosh, 2016).

The local financial markets of both developed and developing countries are open to foreign banks, and the increase in the number of foreign banks in emerging market countries in Latin America and Eastern Europe is particularly evident. Ho (2003) points out that the participation of foreign banks in domestic financial markets will cause many problems and concerns. For example, foreign participation will weaken domestic banks, and due to the impact on the domestic economy, the excessive participation of foreign banks may cause the local domestic banking system to become relatively fragile.

Hermes \& Lensink (2002) found that the participation of foreign banks could lead to a rise in the costs of local banks in developing countries. However, Levine (1996) has argued that the participation of foreign banks will stimulate the development of local banking supervision and relevant legal frameworks and improve the use of international capital. Since the impact of foreign participation varies from developed countries to developing countries, the impact of foreign participation on local bank performance is inconsistent.

The traditional industrial organization theory believes that higher market concentration results in stronger market power for a few large firms. Demsetz (1973) indicated that the inter-industry returns rate and market concentration would be positively correlated in cases of market concentration above $50 \%$. Using 2,704 banks in the US, Smirlock (1985) found that market share and market concentration were positively correlated in terms of the impact on profitability. Berger (1995) discusses the structure of the US financial market, finding that the effect of the enlarged market share after bank mergers was more significant than improvements in efficiency. However, according to the theory of structure-conduct-performance (SCP), market structure will affect business performance without necessarily affecting the behavior of firms. When the market concentration is higher, large firms will have increased profits due to exclusive market power.

There is an abundance of literature on the relationship between market structure and profitability. Market share and concentration are usually analytical tools serving as indicators of market structure. There have been many empirical studies based on the SCP theory. However, the correlation between market structure and the bank interest spread has rarely been discussed in depth. For this reason, this study constructs a 2001-2015 firm-level panel dataset of financial industries in Asian emerging market countries in order to further explore whether the participation of foreign banks, market concentration and the level of competition affects bank performance. Most academic studies have focused on the world, Europe or developed countries, and studies related to Asian emerging countries are inadequate. However, since Asian emerging market countries have become increasingly important in the development of the present financial system, this article selects Asian emerging market countries to discuss and explore new areas of the fast-growing banking system.

\section{DATA SOURCES, EMPIRICAL MODEL AND VARIABLES ADOPTED}

\subsection{Data Sources}

Peria \& Mody (2004) discussed the impact of foreign participation and market concentration in Latin American countries on bank interest spread, pointing out that the banking market structure in developing countries has changed significantly. Accordingly, this study has focused on the period of rapid development in the financial markets in Asian emerging market countries as the research sample and has combined this with bank competition factors to discuss the impact on bank interest spread and the mutual relationships. The research period is from 2001 to 2015 , comprising 15 years of data.

This paper refers to Asian emerging market countries as defined in the MSCI emerging market index and include China, India, Indonesia, Taiwan, Malaysia, the Philippines, Thailand, South Korea and Pakistan as the sample countries. However, since Mainland China is not a country with a floating interest rate, its financial market 
has been excluded from the research due to the lack of sample data and its immaturity. Moreover, the overall variable data for Thailand are inadequate. For sample data consistency, this paper finally limited the emerging market countries studied to Taiwan, India, Indonesia, Malaysia, the Philippines, South Korea and Pakistan. In this paper, 49 banks in Taiwan, 74 banks in India, 76 banks in Indonesia, 49 banks in Malaysia, 57 banks in the Philippines, 28 banks in South Korea and 20 banks in Pakistan make up the study sample.

This paper applies a regression model to examine and compare the financial variables between various banks, and the research data include the financial data and overall variable indicators of the banking industry in various countries. The financial data are taken from the Bankscope database published by Bureau van Dijk Electronic Publishing. The general information is obtained from the International Financial Statistics (IFS) database CDROM compiled by the IMF and IFS Online and includes 32,000 entries of statistical data for more than 200 countries and regions. The data are mainly based on the disk content and commercial banks are the research subjects. For a more complete analysis and discussion of the relationships between the variables, the research period is expanded to cover 2001-2015, with seven Asian emerging market countries serving as the research subjects.

As for the variables in general, the data for some countries are missing. India and Pakistan have relatively closed social patterns, and the extent of information disclosure is insufficient compared with other advanced countries. In addition, data on currency market interest rates in India that are necessary for the calculation of the overall variable for the actual interest rate are missing. Therefore, this paper uses India's benchmark interest rate in the overall economic database as recorded in the TEJ (Taiwan Economic Journal) database to replace the currency market interest rate. With respect to Pakistan, the real industrial growth rate in 2006 is also missing. This study therefore adopts the GNP available on the Pakistan government's website to replace the industrial growth rate after calculation and modification. Finally, the overall data for Taiwan cannot be found on the IFS database CDROM published by the IMF. Therefore, most of the overall data for Taiwan are collected and constructed based on the TEJ and by using the annual time deposit rate of Taiwanese banks as the proxy variable for the currency market interest rate.

\subsection{Construction of the Spread Model}

Based on the spread model referred to by Peria \& Mody (2004), this study applies the multi-regression method to analyze the impact of foreign participation, market concentration and the level of competition on the bank interest spread. The proposed empirical model is illustrated as follows:

$$
\begin{aligned}
\text { Spread }_{i, j, t}= & \alpha_{0}+\alpha_{1} \text { Liquidity }_{i, j, t}+\alpha_{2} \text { Costs }_{i, j, t}+\alpha_{3} \text { NPLs }_{i, j, t}+\alpha_{4} \text { Equity }_{i, j, t}+\alpha_{5} \text { Share }_{i, j, t} \\
& +\alpha_{6} \text { Foreign }_{i, j, t}+\alpha_{7} \text { Concentration }_{j, t}+\alpha_{8} \text { Competition }_{j, t}+\alpha_{9} \text { Growth }_{j, t} \\
& +\alpha_{10} \text { Inflation }_{j, t}+\alpha_{11} \text { Interest }_{j, t}+\alpha_{12} \text { Non-interest }_{j, t}+\alpha_{13} \text { Country dummy }_{i, j, t} \\
& +\varepsilon_{i, j, t}
\end{aligned}
$$

where, $i$ denotes bank $i$; denotes country $j$; and $t$ denotes year $t ; i=1, \ldots, \mathrm{N} ; t=1, \ldots, \mathrm{T}$; and $\varepsilon$ denotes the error term.

In regard to the definitions of the variables in Equation 1 of the model, the spread (Spread) is the gap between the interest income and the spending of the bank; liquidity (Liquidity) is the proportion of liquid assets of the total assets; and operating costs (Costs) is the proportion of operating costs for average assets. Operating costs include the due payroll sum and overhead costs. Non-performing loans (NPLs) represent the amount of overdue loans as a proportion of total loans, and equity (Equity) is the proportion of bank equities vis-à-vis total assets, also known as the equity ratio. The equity ratio based on total assets denotes the self-compensation capability. A higher ratio 
means that better protection is offered to creditors. The bank market share (Share) stands for the loans of each bank as a proportion of the total loans in the banking system. Foreign participation (Foreign) is a dummy variable; it is set as 1 when the shareholding proportion of the local banks by the foreign banks is above $50 \%$, otherwise, it is set as O. Market concentration (Concentration) measures the market share concentration of total assets in the banking system, with the market concentration of the top four banks serving as a proxy variable. The level of competition (Competition) stands for the level of competition of banks in the banking system.

Table 1. Statistics of Variables.

\begin{tabular}{|c|c|c|c|c|}
\hline Variable & Full Sample & Taiwan & Pakistan & Indonesia \\
\hline $\begin{array}{l}\text { Spread } \\
\text { (US\$ million) }\end{array}$ & $\begin{array}{c}2.110 \\
(3.559)\end{array}$ & $\begin{array}{c}2.079 \\
(1.664)\end{array}$ & $\begin{array}{c}2.661 \\
(2.320)\end{array}$ & $\begin{array}{c}2.373 \\
(4.675)\end{array}$ \\
\hline $\begin{array}{l}\text { Liquidity } \\
(\%)\end{array}$ & $\begin{array}{c}0.127 \\
(0.171) \\
\end{array}$ & $\begin{array}{c}0.113 \\
(0.106) \\
\end{array}$ & $\begin{array}{c}0.289 \\
(0.213) \\
\end{array}$ & $\begin{array}{c}0.031 \\
(0.119) \\
\end{array}$ \\
\hline $\begin{array}{l}\text { Costs } \\
(\%)\end{array}$ & $\begin{array}{c}1.450 \\
(11.095)\end{array}$ & $\begin{array}{c}0.017 \\
(0.014)\end{array}$ & $\begin{array}{c}0.025 \\
(0.025)\end{array}$ & $\begin{array}{c}0.026 \\
(0.084)\end{array}$ \\
\hline $\begin{array}{l}\text { NPLs } \\
(\%)\end{array}$ & $\begin{array}{c}2.898 \\
(7.947)\end{array}$ & $\begin{array}{c}2.680 \\
(3.862)\end{array}$ & $\begin{array}{c}6.900 \\
(12.501)\end{array}$ & $\begin{array}{c}2.564 \\
(9.543)\end{array}$ \\
\hline $\begin{array}{l}\text { Equity } \\
(\%)\end{array}$ & $\begin{array}{c}6.002 \\
(10.908) \\
\end{array}$ & $\begin{array}{c}10.060 \\
(16.269) \\
\end{array}$ & $\begin{array}{c}5.250 \\
(5.434) \\
\end{array}$ & $\begin{array}{c}5.603 \\
(12.182)\end{array}$ \\
\hline $\begin{array}{l}\text { Share } \\
(\%)\end{array}$ & $\begin{array}{c}0.005 \\
(0.027) \\
\end{array}$ & $\begin{array}{c}0.001 \\
(0.002) \\
\end{array}$ & $\begin{array}{c}0.067 \\
(0.085) \\
\end{array}$ & $\begin{array}{c}0.001 \\
(0.002) \\
\end{array}$ \\
\hline $\begin{array}{l}\text { Foreign } \\
\text { (dummy variable) }\end{array}$ & $\begin{array}{c}0.293 \\
(0.455)\end{array}$ & $\begin{array}{c}0.265 \\
(0.442)\end{array}$ & $\begin{array}{c}0.200 \\
(0.401)\end{array}$ & $\begin{array}{c}0.248 \\
(0.432)\end{array}$ \\
\hline $\begin{array}{l}\text { Concentration } \\
(\%)\end{array}$ & $\begin{array}{c}0.074 \\
(0.163) \\
\end{array}$ & $\begin{array}{c}0.025 \\
(0.005) \\
\end{array}$ & $\begin{array}{c}0.690 \\
(0.041) \\
\end{array}$ & $\begin{array}{c}0.036 \\
(0.022) \\
\end{array}$ \\
\hline $\begin{array}{l}\text { Competition } \\
\text { (H value) }\end{array}$ & $\begin{array}{c}0.567 \\
(0.473) \\
\end{array}$ & $\begin{array}{c}0.835 \\
(0.632)\end{array}$ & $\begin{array}{c}0.509 \\
(0.431)\end{array}$ & $\begin{array}{c}0.669 \\
(0.458)\end{array}$ \\
\hline $\begin{array}{l}\text { Growth } \\
(\%)\end{array}$ & $\begin{array}{c}0.057 \\
(0.082)\end{array}$ & $\begin{array}{c}0.027 \\
(0.087)\end{array}$ & $\begin{array}{c}0.034 \\
(0.119)\end{array}$ & $\begin{array}{c}0.036 \\
(0.102)\end{array}$ \\
\hline $\begin{array}{l}\text { Inflation } \\
(\%)\end{array}$ & $\begin{array}{c}0.075 \\
(0.093)\end{array}$ & $\begin{array}{c}0.059 \\
(0.151)\end{array}$ & $\begin{array}{c}0.076 \\
(0.033)\end{array}$ & $\begin{array}{c}0.128 \\
(0.128)\end{array}$ \\
\hline $\begin{array}{l}\text { Interest } \\
(\%) \\
\text { Non-interest } \\
\text { (US\$ million) }\end{array}$ & $\begin{array}{c}10.713 \\
(8.548) \\
0.200 \\
(3.077)\end{array}$ & $\begin{array}{c}5.020 \\
(2.398) \\
0.302 \\
(2.368)\end{array}$ & $\begin{array}{c}8.164 \\
(2.928) \\
0.132 \\
(2.725)\end{array}$ & $\begin{array}{c}16.264 \\
(13.641) \\
0.158 \\
(3.612) \\
\end{array}$ \\
\hline No. of Observations & 5,835 & 735 & 375 & 1,515 \\
\hline
\end{tabular}

The bank interest spread may be subject to the impact of the overall banking operating environment, and hence this overall variable is included. Smith (2001) and Peria \& Mody (2004) added the inflation rate (Inflation) to the spread model for two reasons: (1) the spread is the gap between two nominal interest rates and the inflation fluctuations can be reflected by the spread; and (2) (Cottarelli \& Kourelis, 1994) found that inflation will affect the flexibility of lending interest rates and further affect the spread. For real industrial growth, Bernanke \& Gertler (1989) and Kiyotaki \& Moore (1997) suggested that the addition of this variable can help eliminate the factor of business cycles. Finally, the addition of the short-term real interest rate (Interest) is mainly used to control the capital marginal costs facing banks. The inflation rate refers to the continuous rise in general commodity prices at a considerable pace in a given period. It is the depreciation of a currency caused by the fact that the amount of currency exceeds the actual demand for currency in circulation. Real industrial growth (Growth) is the economic indicator representing changes in the production level of the industrial sector. The short-term real interest rate (Interest) is measured by deducting the inflation rate from the currency market interest rates (including the bonds market and the financial lending market). The non-interest income (Non-interest) is measured by fee-based and trading incomes (Lepetit, Nys, Rous, \& Tarazi, 2008). The time-variant variables in a country-specific regression only reflect time trends and do not necessarily depict the macroeconomic dynamics. The macroeconomic variables 
(i.e., Growth, Inflation and Interest) and country dummy variables (including Taiwan, Pakistan, Indonesia, Korea, India and Malaysia) are only included in the full sample model and the omitted dummy variable is that for the Philippines.

\subsection{Further Variable Definitions and Tests}

Foreign participation (Foreign) is a dummy variable. It is set as 1 when the proportion of the shares of local banks held by foreign banks is above $50 \%$, otherwise it is set as 0 . This study selects 12 examples where the foreign bank shareholding is above $50 \%$ among the 49 banks in Taiwan, accounting for $24.49 \%$ of the total. The sample data for banks with foreign ownership above $50 \%$ and below $50 \%$ are shown in Table 1 . The first studies on using market concentration (Concentration) as a measurement standard can be traced back to 1935, and it started to be widely applied after 1947. The indicators frequently used to measure industrial concentration in industrial economies are the market concentration of the top four manufacturers $\left(C R_{4}\right)$ and the market concentration of the top eight manufacturers $\left(C R_{8}\right)$. Shepherd (1985) and Cheng (2006) adopted $\mathrm{CR}_{4}$ as the indicator to measure market concentration when determining market structure. Therefore, this study uses $C R_{4}$ as the indicator to measure market concentration. The market concentration of the top four banks is calculated as follows in Equation 2:

$$
C R_{4}=\sum_{i=1}^{n} S_{i}
$$

where $C R_{4}$ denotes the market concentration of the top four banks, $S_{i}$ denotes the market share of bank $n$, and the accumulated market share of the top four banks $\left(C R_{4}\right)=S_{1}+S_{2}+S_{3}+S_{4}$. This paper uses the total assets of the bank to calculate market share. $\mathrm{A}_{4}$ value in the range of $0 \leq C R_{4} \leq 1$ represents a higher level of market concentration and a greater market monopoly power.

While useful, the concentration ratio presents an incomplete picture of the concentration of firms in an industry because, by definition, it does not use the market share of all the firms in the industry. It also does not provide information regarding the distribution of firm size. The empirical banking literature has shown that concentration is generally a poor measure of competition (Claessens \& Laeven, 2004; Shaffer, 2002). Some authors claim that one of the advantages of the P-R model, as well as of other non-structural models, is that there is no need to specify a relevant market since the behavior of individual firms provides an indication of their market power (De Rozas, 2008). Other advantages of this method are that it requires only a few variables, is robust to the extent that a market exists, and can be estimated by means of a simple, single-equation, linear model (Shaffer, 2004).

Cheng (2006) measured the level of competition of the banking industry (Competition) in 61 countries, stating that the indicators for measuring the level of competition include the traditional industry's organizational concentration $\left(C R_{n}\right)$, the HHI index and the $\mathrm{H}$ value of the P-R model of the new industrial organization theory. The $\mathrm{H}$ value is considered to be the best competition indicator. ${ }^{1}$ Hence, this paper uses the $\mathrm{H}$ value to measure the bank's level of competition to further separate it from $C R_{4}$. The testing equation of the $\mathrm{H}$ value is as follows in Equation 3:

$$
H=\sum_{k=1}^{n} \frac{\partial R}{\partial W_{k}} \frac{W_{k}}{R_{k}}
$$

where $H$ denotes the sum of the flexibility of the price factor against profit, $R$ is the reduced equation for the revenue function, and $W$ represents the prices of the input factors. This paper uses the $\mathrm{H}$ value to determine the level of competition in the banking industry in various countries, and the $H$ value in the banking sectors of various

\footnotetext{
${ }^{1}$ Panzar \& Rosse (1987) proposed the P-R model, which classifies the market structure as being characterized by monopoly power, monopolistic competition and perfect competition, and estimates the variables. Based on the principle of profit maximization, the model uses the profit reduction equation to deduce the $\mathrm{H}$ value.
} 
countries is estimated by the revenue reduction equation. Regarding a bank's level of competition, Molyneux, Thornton, \& Lloyd-Williams (1996) and Cheng (2006); De Rozas (2008); Mamonov (2010); and Arrawatia, Misra, \& Gupta (2012) discussed the meaning of the $\mathrm{H}$ value in the P-R model. When $\mathrm{H}=1$, the financial market is at the full competition state, when the $\mathrm{H}$ value is in the range of $0 \sim 1$, the financial market is in a state of monopolistic competition with free access to equilibrium, and when $\mathrm{H} \leq \mathrm{0}$, the market is in a state of monopolistic equilibrium or is an oligopoly.

\subsection{Competition Environment and Equilibrium Test}

To provide stable conclusions, the competition environment of the banking sector should be tested. Hence, this study uses interest revenue $(I R)$ as a dependent variable to verify the level of competition in the banking sector in terms of services. According to the principles of the competition test, this study assumes that banks operating in a given market structure will adopt different pricing strategies to reflect the changes in input factor costs. Under perfect competition, rising input factor prices will result in concurrent increases in total revenue and marginal costs, and hence the $\mathrm{H}$ value $=1$. Nevertheless, for market monopolistic players in search of maximized profits, the rising prices of the input factors will result in rising marginal costs (a marginal cost curve moving to the right) that will reduce the equilibrium and total revenue (or an unchanged status); therefore, a $\mathrm{H}$ value $<\mathrm{O}$ (or $=0$ ) (Abdul Majid \& Sufian, 2007; Nathan \& Neave, 1989; Panzar \& Rosse, 1987). This study uses interest revenue (IR) as the proxy variable for total revenue and the prices of the inputs as the independent variable in the equation shown below:

$$
\ln I R_{i t}=\beta_{0}+\beta_{1} \ln P_{1, i t}+\beta_{2} \ln P_{2, i t}+\beta_{3} \ln P_{3, i t}+\beta_{4} \ln S_{1, i t}+\beta_{5} \ln S_{2, i t}+\beta_{6} \ln S_{3, i t}+\beta_{7} D+\varepsilon_{i t}
$$

where $i$ is bank $i$, and $t$ is year $t . I R$ is the proportion of interest revenue set against total assets, and $P_{1}$ is the proportion of interest costs set against total deposits, being the proxy variable for the capital price. $P_{2}$ denotes the ratio of human resource costs to total assets, representing the cost of labor; $P_{3}$ denotes the ratio of other operating and management costs to total assets, and stands for the price of equipment or fixed assets; and $\varepsilon$ is the error term. This study uses control variables to control for the differences between banks. $S_{1}$ denotes the ratio of equity to the total assets, and $S_{2}$ stands for the ratio of net loans to total assets. The net loans are equal to the guaranteed loans plus credit loans minus discounts and the provision for bad debts, and $S_{3}$ is the logarithm of the total assets. $D$ is the vector of the time dummy variable during the period from 1991 to 2005 , and the $\mathrm{H}$ value is

the sum of $\beta_{1}+\beta_{2}+\beta_{3}$. Equation 4 uses the OLS method to estimate $\beta_{1}, \beta_{2}$ and $\beta_{3}$ to analyze the panel data in this paper. Finally, Competition is defined as the H value of the OLS estimation $(I R)$ to help determine the state of competition in the financial market.

When using the P-R model to measure market competition, whether or not the market is in equilibrium should be noted. If a bank is in a perfectly competitive market, some manufacturers with losses may not have pulled out of the market in the short term (i.e., the market is in a state of disequilibrium) when factor prices increase. At this time, the product prices have not been adjusted while production has been cut down, making the total revenue decline, and therefore $\mathrm{H}<0$. This is opposite to the behavioral reaction of monopolistic manufacturers in a long-term equilibrium. Hence, due to the overestimation of market monopolistic power, a long-term equilibrium test should be conducted. Shaffer (2002) suggested that input factor prices and return rates have no statistical correlation in 
markets with long-term equilibrium. A market that is not in a long-term equilibrium will result in the overestimation of monopolistic market power because losing manufacturers will not have pulled out of the market in the face of rising market factor prices. The demand curve has not moved to the left, resulting in a reversal of the changes in factor prices and total revenue, namely a market reaction similar to the behavior of monopolistic manufacturers. Hence, after the adjustments of the risk return rates of banks, whether the market is in a long-term state of equilibrium should be tested based on the same principles. Therefore, this study uses the variable $R O A A$ (return on average assets) to replace $I R$, as illustrated below in Equation 5:

$$
\ln R O A A_{i t}=\gamma_{0}+\gamma_{1} \ln P_{1, i t}+\gamma_{2} \ln P_{2, i t}+\gamma_{3} \ln P_{3, i t}+\gamma_{4} \ln S_{1, i t}+\gamma_{5} \ln S_{2, i t}+\gamma_{6} \ln S_{3, i t}+\gamma_{7} D+\varepsilon_{i t}
$$

The return on the average assets of a bank is used as the dependent variable. The independent variable is the same as the one used in the test regarding a bank's competition environment. As a result, the null hypothesis of whether $\gamma_{1}+\gamma_{2}+\gamma_{3}$ is $\mathrm{o}$ should be tested. If the null hypothesis is accepted, then $E=\gamma_{1}+\gamma_{2}+\gamma_{3}=0$, indicating that the market is in equilibrium. If the null hypothesis is rejected, it indicates that banks are in a state of disequilibrium (the Wald test should be used as the testing method). However, such an equilibrium, or the lack of it, does not mean that the competition state of the research sample has changed. It only implies that changes in the banking sector are the result of gradual fluctuations at slightly different paces (Abdul Majid \& Sufian, 2007).

\subsection{Panel Data Empirical Model}

This paper put concentration, competition, foreign participation, equity ratios, and non-performing loans (NPLs) simultaneously as independent variables in our model. Endogeneity issues might occur here because some papers underline that concentration and/or competition might affect NPLs and capital ratios (Berger, Lapper, \& Turk-Ariss, 2008; Soedarmono, Machrouh, \& Tarazi, 2013). Yet, foreign participation can also affect bank competition/concentration (Jeon, Olivero, \& Wu, 2011). The system GMM approach is adopted to implement the empirical estimation. This approach not only considers the endogenous causality, but also derives efficient estimators as it is robust in the presence of heteroskedasticity across firms and correlation among disturbance terms within firms over time (Blundell \& Bond, 1998). The estimation of linear panel data models with predetermined variables is typically conducted by means of the application of GMM estimators to the first difference transformation of the equation of interest, where all the available lags of the predetermined variables are used as instruments. The purpose of this approach is to remove the time-invariant, unobserved, individual heterogeneity. However, this approach yields imprecise estimates in the case of a panel with a small number of time periods with highly persistent data (Blundell \& Bond, 1998).

The system GMM itself is an augmented version that was first outlined by Manuel Arellano \& Bover (1995) and fully developed by Blundell \& Bond (1998). This estimator is based on an augmented system, which includes level equations with lagged differences as instruments in addition to the differenced equations with lagged levels as instruments. As this approach has been verified to perform better than the first-differenced GMM estimator (Badinger, Müller, \& Tondl, 2004; Blundell \& Bond, 2000; Blundell, Bond, \& Windmeijer, 2001), this study thus adopts the system GMM panel regression approach to implement the empirical estimation.

\section{EMPIRICAL RESULTS}

\subsection{Descriptive Statistical Analysis}

The basic statistics of the variables of the spread model are shown in Table 1 and Table 2. In terms of the observation values by country, the maximum value of $\mathrm{CR}_{4}$ occurred in Pakistan, whereas Taiwan had the minimum $\mathrm{CR}_{4}$ value. In terms of spread, the average value for Pakistan was the maximum and the average value for Malaysia, at 1.475 , was the minimum, indicating that banks in Pakistan had the biggest gap between deposit and loan interest 
rates and the best profitability. By comparison, the profitability of banks in Malaysia was the poorest. Banks in Pakistan had the largest market shares, and banks in Taiwan, Indonesia, India, Malaysia and the Philippines had relatively small market shares. The market share of financial institutions in Pakistan was the highest and is characterized by monopolistic power. Regarding the degree of the participation of foreign banks, Malaysia had the highest and the Philippines had the lowest.

Table 2. Statistics of Variables (South Korea, India, Malaysia and Philippines).

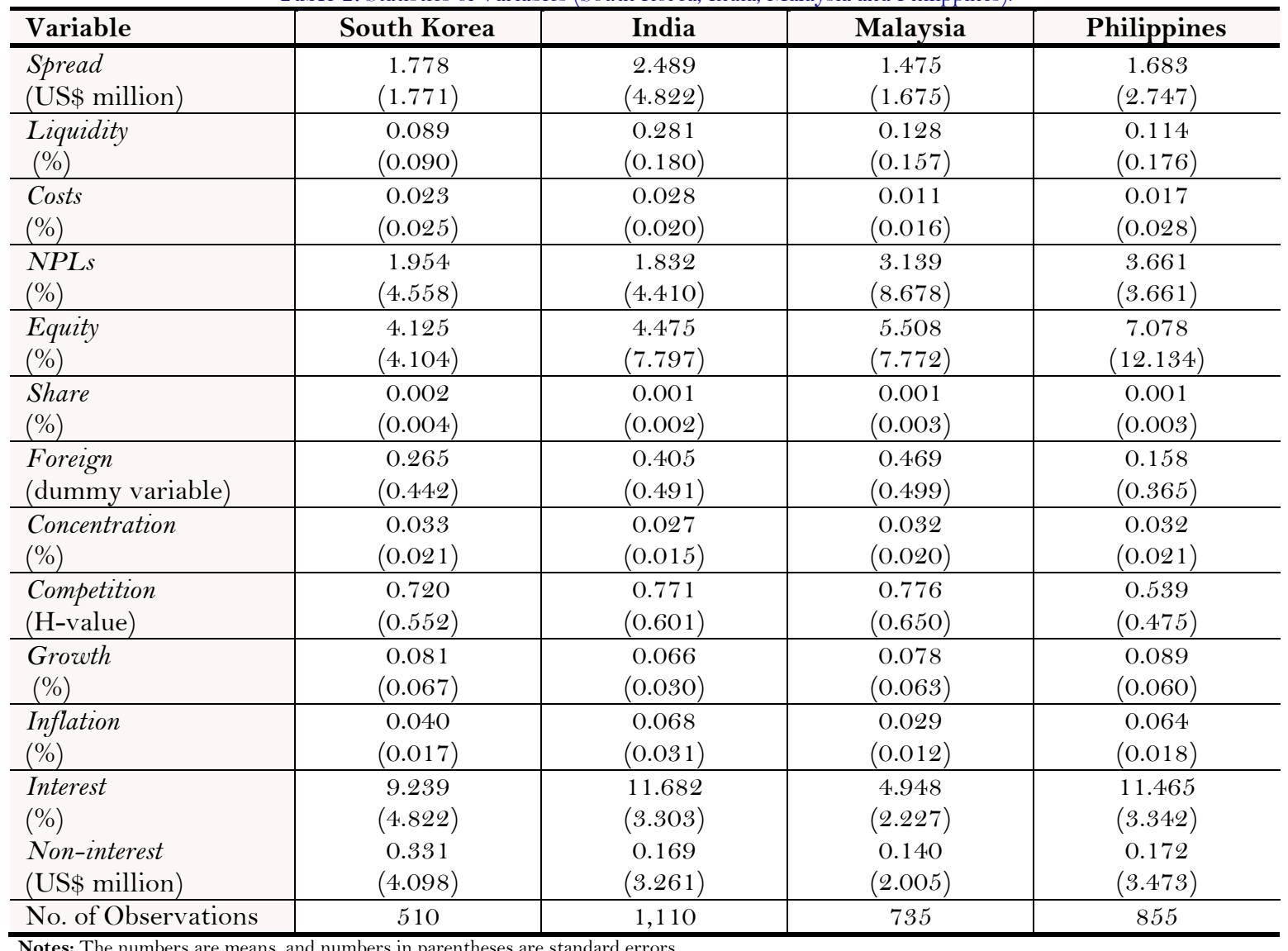

Notes: The numbers are means, and numbers in parentheses are standard errors.

With regard to the level of competition, according to the discussion on the meaning of the $\mathrm{H}$ value in the $\mathrm{P}-\mathrm{R}$ model, when $\mathrm{H}=1$, the banking market is in a state of perfect competition, and when $\mathrm{H}$ is in the range of $0 \sim 1$, the banking market is in a state of balanced monopolistic competition. When $\mathrm{H} \leq \mathrm{o}$, it indicates that the market is in monopolistic equilibrium or a monopolistic state. Taiwan has the highest $\mathrm{H}$ value (0.835) among all countries, and Pakistan has the lowest $\mathrm{H}$ value (0.509) among all countries. With $\mathrm{H}$ lying in the range of $0 \sim 1$ in all countries, this implies that the banking markets are in a state of balanced monopolistic competition during the surveyed period.

The competition situation in Taiwan seems to be more severe than in other Asian emerging financial markets. For the overall sample, the general value of $C R_{\star}$ in Asian emerging markets was 0.074, indicating that the market concentration of the banking systems was not high in general. The level of foreign participation in the overall sample was valued at 0.293, which was lower than that in Malaysia and India, indicating that the degree of foreign participation in those two countries was apparently higher. In addition, the lending rate for the overall sample was 0.005, which was far lower than Pakistan's rate of 0.067, indicating that the lending rate of banks in Pakistan was very high. The spread value of the overall sample was 2.11 , which was not significantly different from the deposit/loan interest spread in other countries.

The basic statistics of the variables related to the competition environment and the equilibrium test are shown in Table 3, in which $I R$ denotes the ratio of the interest revenue against the total assets. India had the highest IR, 
and the Philippines and Malaysia had the lowest. $P_{l}$ stands for the capital price; India had the highest value, and the value for Malaysia was the lowest. $P_{2}$ denotes the price of labor; the value for India was the highest and the value for Taiwan was the lowest. $P_{s}$ denotes the output prices of equipment or fixed assets; the value was the highest in Pakistan, and the lowest values were in Indonesia and Malaysia. $S_{t}$ denotes the proportion of equity against total assets; the proportion in Taiwan was the highest, and the proportion in South Korea was the lowest. $S_{2}$ denotes the proportion of net lending against total assets; the proportion was the highest in Taiwan, and the lowest was in the Philippines. $S_{s}$ is the logarithm value of the total assets; the value for Taiwan was the highest, and the value for the Philippines was the lowest.

\subsection{Empirical Results}

\subsubsection{Selection and Testing of the Appropriate Panel Data Empirical Model}

According to the proposal made by Shaffer (1982) that the P-R model should be constructed in a long-term equilibrium market state, this study uses the Wald test to conduct an equilibrium test to ensure that the market is in a state of equilibrium. If the testing conditions are satisfied, it means that the market is in a state of equilibrium. Next, the $\mathrm{H}$ value, used later on in this article, is shown to be more persuasive. Moreover, as this paper adds the $\mathrm{H}$ value of the P-R model of the competition indicator measurement method, the second part conducts a test of the competition environment of the banking systems. Finally, this paper explains and illustrates the estimation results of various banking financial variables using the spread model.

The empirical results of the equilibrium test are shown in Table 3. Regarding the Asian emerging market as a whole and the other seven countries, this study uses the Wald test to carry out an equilibrium test of the financial market. The testing results suggest that neither the overall financial market nor the financial markets of the seven countries have reached a significance level. Hence, the test results suggest that the financial market is in a state of equilibrium. After confirmation of the equilibrium of the market, on the premise of a long-term equilibrium, this study proposes the $\mathrm{H}$ value of the variable for the competition environment as estimated by the P-R model and integrates the $\mathrm{H}$ value into the constructed spread model.

Regarding the testing results of a competition environment, this study uses the $\mathrm{H}$ value of the P-R model adopted by Cheng (2006) to measure the $\mathrm{H}$ value of the banking system country by country, and then uses the $\mathrm{H}$ value as the standard to measure the level of competition in the banking systems of various countries. The average $\mathrm{H}$ values calculated from the samples of various countries are shown in Table 1 and Table 2. With the $H$ values being in the range of $0 \sim 1$ in all countries, this implies that the banking markets are in a balanced monopolistic competition state during the surveyed period. This result is also consistent with the finding of Arrawatia et al. (2012). Since the concentration ratio and market share are seen as the structural measures of market power, they may be highly correlated and may cause serious multicollinearity problems in the models. Therefore, prior to the measurement of the empirical model, the correlation matrix of variables has been checked to determine whether a serious multicollinearity problem exists in the model. The empirical results of the correlation matrix are shown in Table 4. Due to the lower correlation between $\mathrm{CR}_{4}$ and the market share, and other variables, there is clearly no multicollinearity problem in this model.

Table 5 displays the estimation results for the spread model obtained by applying the system GMM. ${ }^{2}$ The instruments used for the estimation of the first-difference equation are Foreign, Concentration and Competition, dated $(t-2)$ and earlier, in addition to Spread, which is also dated $(t-2)$ and earlier. For the estimation of the level equation, we have added ( $\Delta$ Foreign, $\Delta$ Concentration and $\Delta$ Competition) dated $(t-1)$ and the year dummies as instruments. Before

\footnotetext{
${ }^{2}$ In order to take into account the Windmeijer (2005) robustness checks, the robust estimates are considered in each model. There are various measures used for the dependent variable in the literature. The results are robust since it reaches similar estimators using alternative dependent variable indicators (return on average assets (ROAA)). Please see Table 6 for the robustness checks.
} 
discussing the estimated coefficients, it is crucial to detect the validity of the instrumental variables. We first look at the p-values of the Sargan statistic (also known as Hansen's J-statistic) in the lower part of Table 5 . The $p$-values are larger than a loose critical significance of $10 \%$, suggesting the existence of weak power to validate the instrument being conditional on a set of valid instruments that identify the model. ${ }^{3}$ Thus, the system GMM estimates for the panel data model are well-behaved and help soften the endogeneity problem. Moreover, the two bottom rows in Table 5 show the test results for the serial correlation in $\varepsilon_{i t}\left(m_{1}\right.$ and $\left.m_{2}\right)$. It provides evidence that the assumption of serial uncorrelated errors is appropriate in the model.

The empirical results of the spread model are shown in Table 5. With respect to the full sample, the variables at a significance level with positive effects on the spread include the following: Liquidity, Equity, market share (Share), foreign participation (Foreign), level of competition (Competition), and real interest rate (Interest). The variable for liquidity has a relatively large impact on the spread (a coefficient value of 3.512). It is thus imperative for governments to introduce relevant policies to improve the liquidity of banking institutions. This conclusion is consistent with the view put forward by Peria \& Mody (2004) that liquid assets have an impact on spread.

In addition, both foreign participation and market share are shown to have positive and significant contributions to spreads. That is, when foreign participation and market share are higher, bank performance will be better. These empirical results are consistent with the research conclusions of Levine (1996); Hermes \& Lensink (2002) and Ho (2003), indicating that foreign participation can help the development of the local banking industry, while the rising market share of certain banks is an important sustainable development strategy of the banks. Most previous studies have used the Panzar-Rosse model to construct the level of competition indicator and compare the indicator with market concentration or have measured changes in the level of competition within the financial industry with little discussion on the impact of the level of competition on bank interest spreads or business performance. This paper has integrated the estimated $\mathrm{H}$ value into the empirical model. The research results suggest that a higher level of competition could better help to improve the business performance of banks. Hence, how to increase the competition of the financial industries should be a consideration of the relevant authorities in Asian emerging market countries when formulating policies.

Finally, to sum up the above correlation analysis, the participation of foreign banks has been shown to have no impact on the level of competition, indicating that the two variables have no definite positive or negative correlation. The participation of foreign banks has a positive and significant impact on the spread, indicating that the participation of foreign banks can help improve bank interest spread. However, this is not caused by the changes in the level of competition, but instead encourages the supervision of local banks and the development of relevant legal frameworks. It also enhances the local use of international capital (Levine, 1996) and the use of more advanced business-related technology, as well as improving business skills to further enhance the quality and efficiency of domestic financial industrial businesses and services.

With regard to the overall environment variable, the real interest rate is at the significance level. A higher real interest rate implies higher purchasing power and a higher willingness of investors to invest in markets such as the stock market, funds and other financial investments, thus reducing the costs of deposit interest. Due to the rising demand for funds, the income from the lending interest of the banks will double and furthermore enlarge the bank interest spread.

\footnotetext{
${ }^{3}$ Formally, the Sargan statistic is a test of whether the over-identification restrictions are asymptotically distributed $\chi_{(n-p)}^{2}$, where $n$ is the number of instruments 
Asian Economic and Financial Review, 2022, 12(1): 29-46

Table 3. Statistics of Competitive Environment and Equilibrium Test.

\begin{tabular}{|c|c|c|c|c|c|c|c|c|c|c|c|c|c|c|c|c|}
\hline \multirow{2}{*}{$\frac{\text { Variable }}{I R(\%)}$} & \multicolumn{2}{|c|}{ Full sample } & \multicolumn{2}{|c|}{ Taiwan } & \multicolumn{2}{|c|}{ Pakistan } & \multicolumn{2}{|c|}{ Indonesia } & \multicolumn{2}{|c|}{ South Korea } & \multicolumn{2}{|c|}{ India } & \multicolumn{2}{|c|}{ Malaysia } & \multicolumn{2}{|c|}{ Philippines } \\
\hline & 0.051 & 0.055 & 0.042 & 0.027 & 0.058 & 0.041 & 0.051 & 0.055 & 0.046 & 0.037 & 0.069 & 0.040 & 0.030 & 0.033 & 0.030 & 0.043 \\
\hline$P_{t}(\%)$ & 0.083 & 0.838 & 0.047 & 0.406 & 0.043 & 0.039 & 0.083 & 0.838 & 0.045 & 0.040 & 0.196 & 1.811 & 0.023 & 0.030 & 0.030 & 0.166 \\
\hline$P_{2}(\%)$ & 0.006 & 0.008 & 0.001 & 0.003 & 0.009 & 0.009 & 0.006 & 0.008 & 0.006 & 0.006 & 0.012 & 0.009 & 0.004 & 0.004 & 0.006 & 0.010 \\
\hline$P_{s}(\%)$ & 0.006 & 0.011 & 0.004 & 0.008 & 0.011 & 0.011 & 0.006 & 0.011 & 0.007 & 0.016 & 0.008 & 0.011 & 0.002 & 0.003 & 0.009 & 0.015 \\
\hline$S_{l}(\%)$ & 6.002 & 10.908 & 10.060 & 16.269 & 5.250 & 5.434 & 6.002 & 10.908 & 4.125 & 4.104 & 4.475 & 7.797 & 5.508 & 7.772 & 7.078 & 12.134 \\
\hline$S_{2}(\%)$ & 31.698 & 29.342 & 50.713 & 30.168 & 33.681 & 23.017 & 26.413 & 31.566 & 36.937 & 28.745 & 34.906 & 20.968 & 28.089 & 30.287 & 19.661 & 26.463 \\
\hline $\ln S_{s}$ & 4.338 & 3.856 & 6.824 & 3.805 & 4.690 & 3.054 & 2.665 & 2.908 & 6.010 & 4.638 & 5.738 & 3.380 & 4.051 & 3.918 & 2.442 & 3.196 \\
\hline$R O A A(\%)$ & 0.327 & 3.642 & 0.526 & 1.822 & 0.487 & 1.683 & 0.052 & 6.654 & -0.052 & 0.491 & 0.491 & 1.341 & 0.511 & 1.229 & 0.425 & 1.649 \\
\hline No. of observations & \multicolumn{2}{|c|}{5,835} & \multicolumn{2}{|c|}{735} & \multicolumn{2}{|c|}{375} & \multicolumn{2}{|c|}{1,515} & \multicolumn{2}{|c|}{510} & \multicolumn{2}{|c|}{1,110} & \multicolumn{2}{|c|}{735} & \multicolumn{2}{|c|}{855} \\
\hline Equilibrium Wald test & \multicolumn{2}{|c|}{1.322} & \multicolumn{2}{|c|}{1.623} & \multicolumn{2}{|c|}{1.520} & \multicolumn{2}{|c|}{2.252} & \multicolumn{2}{|c|}{1.226} & \multicolumn{2}{|c|}{1.755} & \multicolumn{2}{|c|}{1.236} & \multicolumn{2}{|c|}{1.969} \\
\hline
\end{tabular}

Table 4. The correlation matrix of variables.

\begin{tabular}{|c|c|c|c|c|c|c|c|c|c|c|c|}
\hline Variable & Liquidity & Costs & NPLs & Equity & Share & Foreign & Concentration & Competition & Growth & Inflation & Interest \\
\hline Liquidity & 1.000 & & & & & & & & & & \\
\hline Costs & -0.005 & 1.000 & & & & & & & & & \\
\hline NPLs & 0.170 & 0.131 & 1.000 & & & & & & & & \\
\hline Equity & 0.105 & -0.015 & 0.055 & 1.000 & & & & & & & \\
\hline Share & 0.106 & -0.002 & 0.119 & 0.030 & 1.000 & & & & & & \\
\hline Foreign & 0.103 & 0.026 & 0.064 & 0.092 & -0.018 & 1.000 & & & & & \\
\hline Concentration & 0.100 & -0.030 & 0.137 & -0.011 & 0.203 & -0.054 & 1.000 & & & & \\
\hline Competition & -0.061 & -0.015 & 0.004 & 0.003 & -0.024 & -0.001 & -0.021 & 1.000 & & & \\
\hline Growth & 0.038 & 0.048 & -0.010 & -0.045 & -0.139 & 0.0124 & -0.098 & -0.022 & 1.000 & & \\
\hline Inflation & -0.115 & -0.056 & -0.066 & -0.018 & -0.008 & -0.034 & 0.001 & 0.108 & -0.039 & 1.000 & \\
\hline Interest & -0.126 & -0.042 & 0.028 & -0.084 & -0.081 & -0.038 & -0.108 & 0.105 & -0.154 & 0.167 & 1.000 \\
\hline Non-interest & -0.023 & -0.015 & 0.021 & -0.060 & -0.011 & -0.019 & -0.005 & 0.107 & -0.098 & 0.063 & -0.107 \\
\hline
\end{tabular}


Asian Economic and Financial Review, 2022, 12(1): 29-46

\begin{tabular}{|c|c|c|c|c|c|c|c|c|c|c|c|c|c|c|c|c|}
\hline \multirow{2}{*}{$\begin{array}{l}\text { Variable } \\
\text { Liquidity }\end{array}$} & \multicolumn{2}{|c|}{ Full Sample } & \multicolumn{2}{|c|}{ Taiwan } & \multicolumn{2}{|c|}{ Pakistan } & \multicolumn{2}{|c|}{ Indonesia } & \multicolumn{2}{|c|}{ South Korea } & \multicolumn{2}{|c|}{ India } & \multicolumn{2}{|c|}{ Malaysia } & \multicolumn{2}{|c|}{ Philippines } \\
\hline & 3.512 & $0.232^{\mathrm{a}}$ & 2.280 & $0.485^{\mathrm{a}}$ & 4.588 & $0.571^{\mathrm{a}}$ & 1.092 & 0.755 & 0.128 & 0.929 & 10.755 & $1.25 \mathrm{O}^{\mathrm{a}}$ & 3.345 & $0.346^{\mathrm{a}}$ & 4.413 & $0.583^{\mathrm{a}}$ \\
\hline Costs & 0.001 & 0.050 & 52.008 & $3.346^{\mathrm{a}}$ & 32.157 & $4.656^{\mathrm{a}}$ & -2.845 & $1.101^{\mathrm{a}}$ & 3.746 & 2.088 & -11.053 & 8.833 & 42.882 & $2.674^{\mathrm{a}}$ & 56.861 & $2.787^{\mathrm{a}}$ \\
\hline NPLs & -0.008 & 0.010 & -3.745 & 2.086 & -0.039 & $0.009^{a}$ & -0.001 & 0.009 & 0.019 & 0.013 & -0.006 & 0.038 & -0.018 & $0.006^{\mathrm{a}}$ & -0.048 & $0.009^{a}$ \\
\hline Equity & 0.218 & $0.008^{a}$ & 0.030 & 0.045 & 0.098 & $0.019^{\mathrm{a}}$ & 0.266 & $0.009^{\mathrm{a}}$ & 0.288 & $0.026^{\mathrm{a}}$ & 0.056 & $0.020^{a}$ & 0.025 & $0.006^{\mathrm{a}}$ & 0.018 & $0.007^{\mathrm{b}}$ \\
\hline Share & 2.933 & $1.604^{\mathrm{b}}$ & 121.190 & 44.473 & -1.086 & 1.173 & 219.029 & $40.140^{\mathrm{a}}$ & 60.881 & $18.034^{\mathrm{a}}$ & 31.486 & 67.430 & 133.320 & $16.722^{\mathrm{a}}$ & 23.454 & 22.113 \\
\hline Foreign & 0.162 & 0.101 & 0.114 & $0.523^{\mathrm{b}}$ & 0.375 & 0.436 & 0.038 & 0.021 & 0.231 & 0.256 & 0.127 & $0.041^{a}$ & 0.011 & 0.124 & 0.163 & 0.102 \\
\hline Concentration & 0.030 & 0.316 & 23.496 & $11.115^{\mathrm{b}}$ & 5.399 & $2.160^{\mathrm{b}}$ & 6.945 & 4.389 & 3.246 & 5.528 & 15.156 & 9.879 & 1.329 & 2.595 & 3.949 & 3.531 \\
\hline Competition & 0.018 & 0.009 & 0.017 & 0.009 & -0.098 & 0.163 & 0.74 & $0.086^{\mathrm{a}}$ & 0.110 & $0.035^{\mathrm{a}}$ & 0.090 & 0.218 & 0.206 & $0.030^{\mathrm{a}}$ & 0.002 & 0.008 \\
\hline Growth & -0.438 & 0.556 & & & & & & & & & & & & & & \\
\hline Inflation & 1.051 & 1.462 & & & & & & & & & & & & & & \\
\hline $\begin{array}{l}\text { Interest } \\
\text { Non-interest }\end{array}$ & $\begin{array}{c}0.013 \\
-0.486 \\
\end{array}$ & $\begin{array}{l}0.008^{\mathrm{a}} \\
0.429 \\
\end{array}$ & -0.152 & 0.163 & -0.227 & 0.269 & -0.389 & 1.022 & -2.459 & 3.118 & 0.487 & 1.201 & -2.132 & 2.669 & 0.075 & 0.165 \\
\hline Country dummy & \multicolumn{2}{|c|}{$\checkmark$} & & & & & & & \\
\hline Year dummy & \multicolumn{2}{|c|}{$\checkmark$} & \multicolumn{2}{|c|}{$\checkmark$} & \multicolumn{2}{|c|}{$\checkmark$} & \multicolumn{2}{|c|}{$\checkmark$} & \multicolumn{2}{|c|}{$\checkmark$} & \multicolumn{2}{|c|}{$\checkmark$} & \multicolumn{2}{|c|}{$\checkmark$} & \multicolumn{2}{|c|}{$\checkmark$} \\
\hline Sargan Test & \multicolumn{2}{|c|}{0.232} & \multicolumn{2}{|c|}{0.465} & \multicolumn{2}{|c|}{0.477} & \multicolumn{2}{|c|}{0.561} & \multicolumn{2}{|c|}{0.433} & \multicolumn{2}{|c|}{0.576} & \multicolumn{2}{|c|}{0.409} & & \\
\hline $\mathrm{m}_{1}(p$-value $)$ & & & 0.2 & & & & 0.2 & & & & 0.2 & & 0. & & & \\
\hline $\mathrm{m}_{2}(p$-value $)$ & & & 0.1 & & & & 0.1 & & & & 0.1 & & 0. & & & \\
\hline $\begin{array}{ll}\begin{array}{l}\text { No. } \\
\text { observations }\end{array} & \text { of } \\
\end{array}$ & & & & & & & 1,5 & & & & & & & & & \\
\hline
\end{tabular}

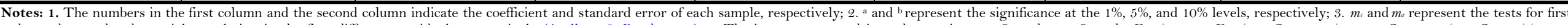

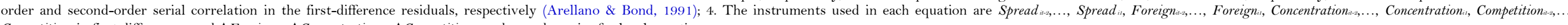

. 
Asian Economic and Financial Review, 2022, 12(1): 29-46

\begin{tabular}{|c|c|c|c|c|c|c|c|c|c|c|c|c|c|c|c|c|}
\hline \multirow{2}{*}{$\frac{\text { Variable }}{\text { Liquidity }}$} & \multicolumn{2}{|c|}{ Full Sample } & \multicolumn{2}{|c|}{ Taiwan } & \multicolumn{2}{|c|}{ Pakistan } & \multicolumn{2}{|c|}{ Indonesia } & \multicolumn{2}{|c|}{ South Korea } & \multicolumn{2}{|c|}{ India } & \multicolumn{2}{|c|}{ Malaysia } & \multicolumn{2}{|c|}{ Philippines } \\
\hline & 1.163 & $0.621^{\mathrm{a}}$ & 1.411 & $0.298^{\mathrm{a}}$ & 1.193 & $0.450^{\mathrm{a}}$ & 2.732 & $1.605^{\mathrm{a}}$ & 1.169 & $0.448^{a}$ & 1.137 & $0.523^{\mathrm{a}}$ & 1.608 & $0.398^{\mathrm{a}}$ & 5.601 & $2.252^{\mathrm{b}}$ \\
\hline Costs & 0.022 & 0.020 & 48.680 & $10.545^{\mathrm{a}}$ & 23.015 & $0.601^{\mathrm{a}}$ & -3.589 & $0.845^{\mathrm{a}}$ & 2.435 & $1.163^{\mathrm{b}}$ & -13.105 & 13.007 & 50.016 & $7.553^{\mathrm{a}}$ & 41.654 & $5.001^{\mathrm{a}}$ \\
\hline NPLs & -0.010 & 0.011 & -5.072 & $0.318^{\mathrm{a}}$ & -0.026 & $0.013^{\mathrm{b}}$ & -0.012 & 0.016 & 0.063 & 0.055 & -0.032 & 0.037 & -0.037 & $0.011^{\mathrm{a}}$ & -0.050 & $0.025^{\mathrm{b}}$ \\
\hline Equity & 0.107 & $0.043^{\mathrm{b}}$ & 0.067 & 0.059 & 0.067 & $0.020^{\mathrm{a}}$ & 0.414 & $0.158^{\mathrm{a}}$ & 0.363 & $0.098^{\mathrm{a}}$ & 0.029 & $0.005^{\mathrm{a}}$ & 0.066 & $0.018^{a}$ & 0.077 & 0.046 \\
\hline Share & 1.262 & $0.622^{\mathrm{b}}$ & 60.828 & $9.169^{\mathrm{a}}$ & -1.069 & 1.100 & 25.628 & $3.957^{\mathrm{a}}$ & 68.200 & $15.135^{\mathrm{a}}$ & 26.773 & 37.070 & 11.619 & $2.039^{\mathrm{a}}$ & 15.002 & 17.257 \\
\hline Foreign & 0.264 & 0.153 & 0.053 & $0.023^{b}$ & 0.383 & 0.396 & 0.036 & $0.008^{\mathrm{a}}$ & 0.288 & 0.273 & 0.165 & $0.105^{c}$ & 0.069 & 0.131 & 0.128 & $0.047^{\mathrm{a}}$ \\
\hline Concentration & 0.043 & 0.258 & 26.422 & $15.378^{\mathrm{c}}$ & 5.071 & $2.003^{\mathrm{b}}$ & 5.113 & 4.864 & 3.007 & 4.105 & 12.651 & 11.992 & 1.669 & 2.003 & 2.804 & 2.779 \\
\hline Competition & 0.009 & $0.005^{c}$ & 0.038 & 0.041 & -0.157 & 0.160 & 0.290 & $0.088^{\mathrm{a}}$ & 0.013 & $0.008^{\mathrm{c}}$ & 0.085 & 0.163 & 0.036 & $0.005^{\mathrm{a}}$ & 0.078 & 0.096 \\
\hline Growth & -0.516 & 0.600 & & & & & & & & & & & & & & \\
\hline Inflation & 1.311 & 1.503 & & & & & & & & & & & & & & \\
\hline $\begin{array}{l}\text { Interest } \\
\text { Non-interest }\end{array}$ & $\begin{array}{c}0.003 \\
-0.552\end{array}$ & $\begin{array}{l}0.002 \\
0.530\end{array}$ & -0.187 & 0.178 & -0.273 & 0.253 & -0.321 & 1.107 & -2.332 & 3.098 & 0.650 & 1.333 & -2.208 & 2.878 & 0.059 & 0.165 \\
\hline Country dummy & \multicolumn{2}{|c|}{$\checkmark$} & & \multicolumn{2}{|c|}{+2} & \multicolumn{2}{|c|}{+2} & \multirow{2}{*}{\multicolumn{2}{|c|}{$\checkmark$}} & \multicolumn{2}{|c|}{+2} & \multicolumn{2}{|c|}{+2} & \multicolumn{2}{|c|}{ (2) } \\
\hline Year dummy & \multicolumn{2}{|c|}{$\checkmark$} & \multicolumn{2}{|c|}{$\checkmark$} & \multirow{2}{*}{\multicolumn{2}{|c|}{$\begin{array}{c}\checkmark \\
0.401\end{array}$}} & \multicolumn{2}{|c|}{$\checkmark$} & & & r & & , & & & \\
\hline Sargan Test & \multicolumn{2}{|c|}{0.330} & \multirow{2}{*}{\multicolumn{2}{|c|}{$\begin{array}{l}0.497 \\
0.239\end{array}$}} & & & \multirow{2}{*}{\multicolumn{2}{|c|}{$\begin{array}{l}0.586 \\
0.280\end{array}$}} & \multicolumn{2}{|c|}{0.419} & \multicolumn{2}{|c|}{0.598} & \multicolumn{2}{|c|}{0.453} & & \\
\hline $\mathrm{m}_{1}$ (p-value $)$ & & & & & \multicolumn{2}{|c|}{0.271} & & & \multicolumn{2}{|c|}{0.223} & \multicolumn{2}{|c|}{0.229} & \multicolumn{2}{|c|}{0.252} & & \\
\hline $\mathrm{m}_{2}(p$-value $)$ & & & & & 0.1 & & 0.1 & & & 53 & 0.1 & & & & & 50 \\
\hline No. of observations & 5,8 & & 7 & & $3^{\prime}$ & & 1,5 & & & 0 & 1,1 & & & & & 5 \\
\hline
\end{tabular}

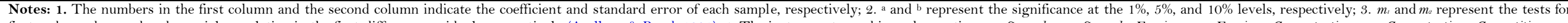

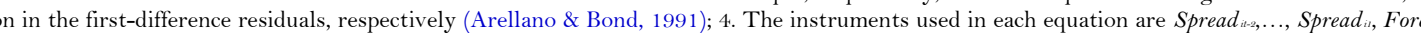

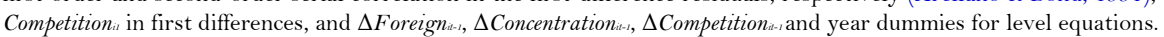


With regard to the empirical results of the sub-samples of various countries, the market concentration of banks in Taiwan has a positive and significant impact on the spread, and the impact is the greatest compared with other variables. This conclusion is consistent with the findings of studies by Smirlock (1985); Berger (1995); Lee (2001) and Gao (2008), which confirmed the viewpoint that market concentration can help the local banking industry to develop. As a foreign businessman in Hong Kong, the Head of the Greater China Division of McKinsey, Mr. Yao, has pointed out that Taiwan should speed up its efforts to create a large bank with international competitiveness and a market share of around $10 \%$ to $15 \%$. This viewpoint makes it imperative to promote the market concentration of the banking industry in Taiwan. The foreign banks' participation in Taiwan also has a positive and significant impact on the spread. In Pakistan, market concentration has a significant and positive impact on the spread, indicating that bank interest spreads will tend to increase along with the rising market concentration of banks. Other significant variables, including liquid assets, operating costs, non-performing loans and equity have a greater impact on changes in the spread. The empirical results by Peng \& Wu (2006) suggest that banks with a high efficiency value, a large asset scale and a low NPL ratio will have better business performance. As for Indonesia, banking competition has had a significant impact. That is, when financial markets are highly competitive in Indonesia, the impact on the bank interest spread will be more significant.

With respect to South Korea, the banking competition has had a positive impact on the spread. The participation of foreign banks in India has also had a positive impact on the spread. In addition, in the case of Malaysia, market share and the level of competition has had a significant and positive impact on the spread, indicating that a higher market share and competition has increased the spread in the Malaysian financial markets. Finally, foreign participation has been shown to be quite an important feature of the banking industry in the Philippines. In 1872, Standard Chartered Bank established branches in the Philippines, becoming the first foreign bank in the country. During the period from 1995 to 2004, the number of foreign banks increased by 14; however, no new foreign banks joined the market after 2002. Foreign banks were more willing to provide capital to the market than local banks, helping to solve the problem of a lack of funds for the economic growth of the Philippines. The empirical data suggested that the participation of foreign banks had a significant impact on the spread in Philippines.

\section{CONCLUSIONS AND SUGGESTIONS}

4.1. Conclusions

First, regarding the overall sample, the participation of foreign banks has had a positive and significant impact on the bank interest spread, suggesting that the participation of foreign banks is a major factor influencing the bank interest spread in the general financial markets in Asian emerging market countries, and that more foreign banks in local financial markets can help improve bank performance. The findings of this paper are different from the empirical results of Peria \& Mody (2004) in that the participation of foreign banks directly affects the bank interest spread via operating costs in Latin American countries. The reason for such differences may be that competition in Asian emerging market countries is not as fierce as in Latin America. Foreign banks could not win clients by lowering the bank interest spread when entering local financial markets. From the perspective of various countries, in Taiwan, Indonesia, India, and Philippines, foreign participation has a positive impact on the spread.

The positive impact of the participation of foreign banks on the spread indicates that the participation of foreign banks could help improve the bank interest spread, but this is not caused by changes in the level of competition. Instead, foreign participation will stimulate the development of local banking supervision and relevant legal frameworks and improve the use of international capital. In addition, foreign participation can strengthen inter-bank competition and enable local banking industries to use advanced business-related technologies to improve business skills and enhance the quality and efficiency of financial businesses and the service of domestic financial systems (Levine, 1996). For example, the Kookmin Bank of South Korea introduced the Goldman Sachs 
Group, discussing major business decisions with them to learn about new investment banking and asset management technology. The Dutch Barings Bank has helped train staff at the Korea Housing Bank, introducing new trends in Western consumer financing.

Second, regarding discussions on market concentration, the data suggest that it had a positive impact on the spread in the total sample or in Asian emerging market countries, especially in Taiwan and Pakistan. It could thus be learnt that the financial market concentration in Taiwan and Pakistan has had a relatively greater impact on business performance. This conclusion is consistent with the empirical results of Peria \& Mody (2004), that banking concentration can significantly affect the bank interest spread in a positive direction, indicating that market concentration has had a significant impact on the bank interest spread, whether in Latin American or Asian emerging market countries.

Finally, the level of competition had a significant and positive impact on the spread in Indonesia, South Korea and Malaysia, suggesting that a higher level of competition can result in a bigger bank interest spread. This conclusion is consistent with the view put forward by Goldberg \& Rai (1996); Smith (1998) and Coccorese (2004), that the level of competition of banks will increase with the rising economic benefits of a certain country or region, making positive contributions to overall economic performance.

\subsection{Suggestions}

With regard to making suggestions to the competent authorities of Taiwan, as indicated by the empirical results for Taiwan, the positive impact of the participation of foreign banks on the spread is insignificant, indicating that the participation of foreign banks does impact the business performance of local banks. Hence, it is suggested that the government may relax or open the local market to foreign investments to increase the profitability of local banks and promote the competitiveness and globalization of the domestic financial system. Therefore, the benefits of foreign participation cannot be reflected in bank operating performance. Although the percentage of foreign banks in the Taiwanese financial market is relatively low compared with that of local banks, the fierce competition among banks will help develop the Taiwanese financial market, which merits the attention of the banking authorities. As a consequence, it is suggested that the authorities should introduce foreign banks to the Taiwanese financial market to improve the competitiveness of local banks. However, it should be considered whether foreign banks will have a negative impact on the financial market if the legal or supervisory systems established by the banking authorities are inadequate. The empirical results of this paper suggest that both foreign participation and domestic market concentration could help improve the business performance of local banks. As there is no absolute correlation between the two variables, relevant government units should consider improving bank performance via different routes when introducing policies or drafting relevant rules and regulations.

With respect to bank operators, since market concentration has a significant and positive impact on the business performance of the Taiwanese financial market, the moderate merging of domestic banks to increase market concentration, without the introduction of foreign funds, can result in positive benefits to the development of the Taiwanese financial industry. This confirms the urgent need for a second series of financial reforms and the establishment of financial holding companies as recently implemented by the Taiwan government. In addition, faced with increasingly fierce competition in the financial system, more business services should be launched to increase product diversity and expand overseas branches to more rapidly respond to financial developments and gain better profitability.

With respect to the level of competition of banks, this paper uses different variables to measure various factors of the $\mathrm{H}$ value of the P-R model. For future studies, it is suggested that new testing methods should be developed to further test the range of reasonable applications of the $\mathrm{H}$ value. In addition, this study has only used data up to 2005 from Bankscope. It is suggested that follow-up studies should extend the research period to test recent changes in the banking environment. Due to the limitations imposed by the data, this study did not include Mainland China 
and Thailand, two Asian emerging market countries that were originally within the scope of this research. Nevertheless, China is doing very well economically, and Thailand has been growing rapidly ever since the Asian financial crisis. Follow-up studies could further explore the changes taking place in the current financial situations of Asian emerging market countries. In addition, the bank attribute of state ownership or private ownership is also a key variable. This clearly-defined variable may help reduce the estimation bias. Finally, future studies may further explore the impact of foreign participation on bank performance by distinguishing the differences before and after foreign participation, though some previous studies have also explored the non-linear effect of bank competition (Berger, DeYoung, Flannery, Lee, \& Öztekin, 2008).

Funding: Financial support provided by the Taiwan National Science Council through grant MOST 1042410-H-324-002 is gratefully acknowledged.

Competing Interests: The author declares that there are no conflicts of interests regarding the publication of this paper.

\section{REFERENCES}

Abdul Majid, M. Z., \& Sufian, F. (2007). Market structure and competition in emerging market: Evidence from Malaysian Islamic banking industry. Journal of Economic Cooperation, 2(28), 99-121.

Arellano, M., \& Bond, S. (1991). Some tests of specification for panel data: Monte Carlo evidence and an application to employment equations. Review of Economic Studies, 58(2), 277-297. Available at: https://doi.org/10.2307/2297968.

Arellano, M., \& Bover, O. (1995). Another look at the instrumental variable estimation of error-components models. Journal of Econometrics, 68(1), 29-51. Available at: https://doi.org/10.1016/0304-4076(94)01642-d.

Arrawatia, R., Misra, A., \& Gupta, V. (2012). Assessment of competition in Indian banking. European Journal of Business and Management, 4(20), 159-169.

Badinger, H., Müller, W., \& Tondl, G. (2004). Regional convergence in the European Union, 1985-1999: A spatial dynamic panel analysis. Regional Studies, 38(3), 241-253. Available at: https://doi.org/10.1080/003434042000211105.

Beck, T., \& Peria, M. S. M. (2010). Foreign bank participation and outreach: Evidence from Mexico. Journal of Financial Intermediation, 19(1), 52-73. Available at: https://doi.org/10.1016/j.jfi.2009.03.002.

Berger, A. N., Lapper, L. F. K., \& Turk-Ariss, R. (2008). Bank competition and financial stability. Policy Research Working Paper, No. 4696.

Berger, A. N. (1995). The profit-structure relationship in banking--tests of market-power and efficient-structure hypotheses. Journal of Money, Credit and Banking, 27(2), 404-43 1. Available at: https://doi.org/10.2307/2077876.

Berger, A. N., DeYoung, R., Flannery, M. J., Lee, D., \& Öztekin, Ö. (2008). How do large banking organizations manage their capital ratios? Journal of Financial Services Research, 34(2), 123-149. Available at: https://doi.org/10.1007/s 10693-0080044-5.

Bernanke, B., \& Gertler, M. (1989). Agency costs, net worth, and business fluctuations. American Economic Review, 79, 14-31.

Blundell, R., \& Bond, S. (1998). Initial conditions and moment restrictions in dynamic panel data models. Journal of Econometrics, 87(1), 115-143. Available at: https://doi.org/10.1016/s0304-4076(98)00009-8.

Blundell, R., \& Bond, S. (2000). GMM estimation with persistent panel data: An application to production functions. Econometric Reviews, 19(3), 321-340. Available at: https://doi.org/10.1080/07474930008800475.

Blundell, R., Bond, S., \& Windmeijer, F. (2001). Estimation in dynamic panel data models: Improving the performance of the standard GMM estimators. Advances in Econometrics, 15, 53-91.

Cheng, J. K. (2006). Banking competition and competitive determinants - international evidence. Master Dissertation, National Taipei University.

Claessens, S., \& Laeven, L. (2004). What drives bank competition? Some international evidence. Journal of Money, Credit \&o Banking, 36(3), S563-S563. Available at: https://doi.org/10.1353/mcb.2004.0044. 
Coccorese, P. (2004). Banking competition and macroeconomic conditions: A disaggregate analysis. Journal of International Financial Markets, Institutions and Money, 14(3), 203-2 19. Available at: https://doi.org/10.1016/j.intfin.2003.07.001.

Cottarelli, C., \& Kourelis, A. (1994). Financial structure, bank lending rates, and the transmission mechanism of monetary policy. Staff Papers, 41(4), 587-623. Available at: https://doi.org/10.2307/3867521.

De Rozas, G. L. (2008). Testing for competition in the Spanish banking industry: The Panzar-Rosse approach revisited. Bank of Spain Working Paper, No. 0726.

Degirmen, S. (2011). The effects of foreign bank participation on the Turkish banking system and crisis. American Sociological Association, 17, 515-531. Available at: https://doi.org/10.5195/jwsr.2011.404.

Demsetz, H. (1973). Industry structure, market rivalry, and public policy. The Journal of Law and Economics, 16(1), 1-9. Available at: https://doi.org/10.1086/466752.

Gao, X. Y. (2008). The analysis of concentration and earning ability from the Taiwanese insurance industry. Ling Tung Journal, 23, 125-147.

Ghosh, S. (2016). Foreign banks in MENA countries: How important? How relevant? Journal of Economic and Administrative Sciences, 32(1), 77-98. Available at: https://doi.org/10.1108/jeas-11-2014-0031.

Goldberg, L. G., \& Rai, A. (1996). The structure-performance relationship for European banking. Journal of Banking $\mathbb{E}^{2}$ Finance, 2O(4), 745-771. Available at: https://doi.org/10.1016/0378-4266(95)0002 1-6.

Hermes, N., \& Lensink, R. (2002). The impact of foreign bank entry on domestic banking markets: A note. Paper presented at the University of Groningen, Research Institute SOM (Systems, Organisation and Management).

Ho, S. Y. (2003). Foreign bank entry - the impact of experience and mean detection on the local markets of developing vs. developed countries. Master's Dissertation, National Chengchi University.

Jeon, B. N., Olivero, M. P., \& Wu, J. (2011). Do foreign banks increase competition? Evidence from emerging Asian and Latin American banking markets. Journal of Banking \& Finance, 35(4), 856-875. Available at: https://doi.org/10.1016/j.jbankfin.2010.10.012.

Kiyotaki, N., \& Moore, J. (1997). Credit chains. Journal of Political Economy, 105(21), 21 1-248.

Lee, Y. (2001). Relationship between profitability, market structure and efficiency in Taiwan life insurance industry. Insurance Monograph, 65, 30-63.

Lepetit, L., Nys, E., Rous, P., \& Tarazi, A. (2008). Bank income structure and risk: An empirical analysis of European banks. Journal of Banking ङ Finance, 32(8), 1452-1467. Available at: https://doi.org/10.1016/j.jbankfin.2007.12.002.

Levine, R., \& Zervos, S. (1996). Stock market development and long-run growth. The World Bank Economic Revierw, 1O(2), 323339. Available at: https://doi.org/10.1093/wber/10.2.323.

Levine, R. (1996). Foreign banks, financial development, and economic growth. In International Financial Markets: Harmonization versus Competition, edited by C.E. Barfield (pp. 224-254). Washington, DC: American Enterprise Institute Press.

Mamonov, M. (2010). Testing for competition in the Russian banking sector within the Panzar-Rosse approach: Theoretical and empirical framework. Applied Econometrics, 20(4), 3-27.

Molyneux, P., Thornton, J., \& Lloyd-Williams, D. M. (1996). Competition and market contestability in Japanese commercial banking. Journal of Economics and Business, 48(1), 33-45. Available at: https://doi.org/10.1016/0148-6195(95)00047-x.

Nathan, A., \& Neave, E. H. (1989). Competition and contestability in Canada's financial system: Empirical results. Canadian Journal of Economics, 22(3), 576-594. Available at: https://doi.org/10.2307/135541.

Panzar, J. C., \& Rosse, J. N. (1987). Testing for" monopoly" equilibrium. Journal of Industrial Economics, 35(4), 443-456. Available at: https://doi.org/10.2307/2098582.

Peng, Y. H., \& Wu, T. T. (2006). Study on the performance and characteristics of banks under financial holding companies in Taiwan. Journal of Performance and Strategy Research, 3(1), 19-32. 
Peria, M. S. M., \& Mody, A. (2004). How foreign participation and market concentration impact bank spread: Evidence from

Latin America. Journal of Money, Credit, and Banking, 36, 511-537. Available at: https://doi.org/10.1353/mcb.2004.0048.

Shaffer, S. (2002). Competitive bank pricing and adverse selection, with implications for testing the SCP hypothesis. The Quarterly Review of Economics and Finance, 42(3), 633-647. Available at: https://doi.org/10.1016/s1062-9769(01)000874.

Shaffer, S. (2004). Comment on "What drives bank competition? Some international evidence" by Stijin claessens and Luc Laeven. Journal of Money, Credit, and Banking, 36, 585-592. Available at: https://doi.org/10.1353/mcb.2004.0050.

Shaffer, S. (1982). A non-structural test for competition in financial markets. Paper presented at the Proceedings of A Conference in Bank Structure and Competition. (Chicago: Federal Reserve Bank of Chicago).

Shepherd, W. G. (1985). The economics of industrial organization (2nd ed.). Englewood Cliffs, NJ: Prentice-Hall, Inc.

Smirlock, M. (1985). Evidence on the (non) relationship between concentration and profitability in banking. Journal of Money, Credit and Banking, 17(1), 69-83. Available at: https://doi.org/10.2307/1992507.

Smith, R. T. (2001). Bank spreads and business cycles. Mimeo: IMF.

Smith, R. (1998). Banking competition and macroeconomic performance. Journal of Money, Credit and Banking, 30(4), 793-815. Available at: https://doi.org/10.2307/2601129.

Soedarmono, W., Machrouh, F., \& Tarazi, A. (2013). Bank competition, crisis and risk taking: Evidence from emerging markets in Asia. Journal of International Financial Markets, Institutions and Money, 23, 196-221. Available at: https://doi.org/10.1016/j.intfin.2012.09.009.

Windmeijer, F. (2005). A finite sample correction for the variance of linear efficient two-step GMM estimators. Journal of Econometrics, 126(1), 25-51. Available at: https://doi.org/10.1016/j.jeconom.2004.02.005.

Views and opinions expressed in this article are the views and opinions of the author(s), Asian Economic and Financial Review shall not be responsible or answerable for any loss, damage or liability etc. caused in relation to/arising out of the use of the content. 